\title{
VEGFR1/CXCR4-positive progenitor cells modulate local inflammation and augment tissue perfusion by a SDF-1-dependent mechanism
}

\author{
Andrew Wragg • Jason A. Mellad • Leilani E. Beltran • \\ Mikhail Konoplyannikov • Hong San • Sherry Boozer • \\ Robert J. Deans - Anthony Mathur • \\ Robert J. Lederman • Jason C. Kovacic • \\ Manfred Boehm
}

Received: 19 October 2007 /Revised: 13 June 2008 / Accepted: 20 June 2008 / Published online: 9 August 2008

(C) The Author(s) 2008

\begin{abstract}
Recruitment and retention of circulating progenitor cells at the site of injured or ischemic tissues facilitates adult neo-vascularization. We hypothesized that cell therapy could modulate local neo-vascularization through the vascular endothelial growth factor (VEGF)/stromal cellderived factor-1 (SDF-1) axis and by paracrine effects on local endothelial cells. We isolated from rat bone marrow a subset of multipotent adult progenitor cell-derived progenitor cells (MDPC). In vitro, MDPCs secreted multiple cytokines related to inflammation and angiogenesis, including monocyte chemotactic protein-1, SDF-1, basic fibroblast growth factor, and VEGF, and expressed the chemokine receptors CXCR4 and VEGFR1. To investigate in vivo properties, we transplanted MDPCs into the ischemic hind limbs of rats. Elevated levels of the chemokine SDF-1 and colocalization of $\mathrm{CD}_{11 \mathrm{~b}^{+}}$cells marked the initial phase of tissue remodeling after cell transplantation. Prolonged engraftment was observed in the adventitialmedial border region of arterioles of ischemic muscles.
\end{abstract}

A. Wragg $\cdot$ J. A. Mellad $\cdot$ L. E. Beltran $\cdot$ M. Konoplyannikov $\cdot$

H. San $\cdot$ R. J. Lederman $\cdot$ J. C. Kovacic $\cdot$ M. Boehm $(\bowtie)$

Translational Medicine Branch, National Heart,

Lung, and Blood Institute, National Institutes of Health,

Building 10-CRC, Room 5-3132,

Bethesda, MD 20817, USA

e-mail: boehmm@nhlbi.nih.gov

S. Boozer $\cdot$ R. J. Deans

Athersys,

Cleveland, OH 44115, USA

A. Wragg · A. Mathur

William Harvey Research Institute, Barts and the London,

London EC1M 6BQ, UK
However, engrafted cells did not differentiate into endothelial or smooth muscle cells. Limb perfusion normalized 4 weeks after cell injection. Inhibition of SDF-1 reduced the engraftment of transplanted cells and decreased endothelial cell proliferation. These findings suggest a two-stage model whereby transplanted MDPCs modulate wound repair through recruitment of inflammatory cells to ischemic tissue. This is an important potential mechanism for cell transplantation, in addition to the direct modulation of local vascular cells through paracrine mechanisms.

Keywords Vascular biology · Cell therapy Stem cell . Inflammation

\section{Introduction}

Bone marrow-derived cells, including endothelial progenitor cells [1], hematopoietic stem cells [2], and mesenchymal stromal cells (MSCs) [3], may have the potential to differentiate into cellular components of the vasculature and increase the perfusion of ischemic organs. Recent clinical trials have shown improvement of cardiac function after infusion of bone marrow-derived cells [4, 5]. However, comparable studies have failed to demonstrate improvement of cardiac function [6]. It is crucial that more studies are performed to understand the mechanism of cardiovascular repair.

The transplantation of cell types capable of multilineage differentiation to restore the multiple cell types required to improve function in a diseased organ has inherent appeal. Nonembryonic multipotent and/or pluripotent progenitor 
cell populations have recently been cultured from bone marrow, muscle, and umbilical cord blood [7-10]. These cells all exhibit substantial replicative potential and are capable of differentiation into various cell types belonging to different embryonic germ layers in vitro. These progenitor cells may be beneficial in certain disease models, including myocardial infarction [10]. Multipotent adult progenitor cells (MAPCs) are an example of a pluripotent progenitor population which can be cultured from the adult bone marrow of humans, mice, and rats [7].

Originally, it was suggested that bone marrow-derived cells differentiate into vascular cells that integrate into new blood vessels [1]. However, the level of engraftment is often minimal or absent despite significant improvements in perfusion [11]. Several alternative mechanisms to cell differentiation have been proposed. These include cell fusion [12], angiogenic growth factor delivery [13], and the modulation of endogenous stem or progenitor cell function by the release of the stem cell-homing cytokine stromal cellderived factor-1 (SDF-1) [14-16]. However, any mechanism of engraftment and differentiation is likely to be a complex process with interactions between the transplanted cells and host physiological signals. Evidence suggests that vascular endothelial growth factor (VEGF) may mediate this process by initiating a cascade of events including the local release of SDF-1. VEGF is known to recruit bone marrow-derived inflammatory cells to ischemic vessels, with SDF-1, then facilitating their retention via the chemokine receptor CXCR4 [17, 18]. Although it is not clear whether bone marrow-derived cells acquire an endothelial cell phenotype, evidence suggests that recruited bone marrow-derived cells secrete multiple factors that ultimately induce the proliferation of local endothelial cells and angiogenesis.

In this study, we explored two possible mechanisms that may lead to improved tissue perfusion. First is the ability of multipotent progenitor cells to regenerate vasculature. Second is the role of paracrine effects on vascular remodeling. Bone marrow-derived cells were cultured under MAPC conditions and displayed in vitro properties similar to MAPCs. We named these cells MAPC-derived progenitor cells or MDPCs. When transplanted into a rat ischemic hind limb model, MDPCs engrafted selectively into the adventitial-medial border region of arterioles. Although engrafted cells did not differentiate into endothelial or vascular smooth muscle cells, we observed an enhanced activation of the VEGF/SDF-1 system that resulted in homing and recruitment of $\mathrm{CD}_{11} \mathrm{~b}^{+}$myeloid cells. Inhibition of SDF-1/CXCR4 function decreased the engraftment of transplanted MDPCs and endothelial cell proliferation. We propose that, through paracrine mechanisms, MDPC transplantation affects tissue remodeling and increases tissue perfusion through modulation of the local immune response. The VEGF/SDF-1 system appears to have a pivotal role in this process and is an important additional mechanism.

\section{Materials and methods}

Animal model

12-14-week-old female inbred Fisher 344 rats (Harlan, Indiana, USA) underwent femoral artery excision to induce chronic limb-threatening ischemia and served as recipients for cell transplantation. Assessment of perfusion data was blinded. All experiments were conducted according to the guidelines of the Animal Care and Use Committee of the National Heart, Lung, and Blood Institute and the guide for the Care and Use of Laboratory Animals published by the US National Institutes of Health (NIH Publication no. 8523, revised 1996).

\section{Isolation of MDPCs}

MDPCs were isolated from 8-week-old male Fisher 344 rats and cultured based on protocols previously established for MAPCs [7]. Briefly, bone marrow was harvested and cultured in T175 polystyrene culture flasks coated with $10 \mathrm{ng} / \mathrm{ml}$ fibronectin (Sigma-Aldrich, St Louis, MO, USA) in basal media consisting of $60 \%$ Dulbecco's modified Eagle's medium (low glucose; Gibco, Carlsbad, CA, USA), 40\% MCDB 201 (Sigma-Aldrich), with $1 \times$ insulin-transferrinselenium, $1 \times$ linoleic acid-bovine serum albumin (BSA), $0.5 \mu \mathrm{M}$ dexamethasone, $0.1 \mathrm{mM}$ ascorbic acid 2-phosphate, $100 \mathrm{U}$ penicillin-streptomycin (all Sigma-Aldrich), supplemented with $10 \mathrm{ng} / \mathrm{ml}$ platelet-derived growth factor (PDGF)-BB (R\&D, Minneapolis, MN, USA), $10 \mathrm{ng} / \mathrm{ml}$ epidermal growth factor (Sigma-Aldrich), $10^{3} \mathrm{U} / \mathrm{ml}$ leukocyte inhibitory factor (Chemicon, Temecula, CA, USA), and $2 \%$ fetal bovine serum (Hyclone, Logan, UT, USA). After 2 days, nonadherent cells were discarded, and media were subsequently changed every $48-72 \mathrm{~h}$. Colonies of proliferating cells were harvested after 7 days with trypsin/ ethylenediamine tetraacetic acid (EDTA) and recultured at a density of 200 cells per $\mathrm{cm}^{2}$. Cells were maintained at low density by being split every $48-72 \mathrm{~h}$. At each passage, cells were enumerated with a hemocytometer. A single-cell cloning step was not undertaken. To enable identification of transplanted cells, MDPCs were transduced with a retrovirus carrying the LacZ plasmid pCL-MFG-LacZ (Imgenex, San Diego, CA, USA).

Flow cytometry

MDPCs were collected with trypsin/EDTA and washed with fluorescence-activated cell sorting (FACS) wash 
(phosphate-buffered saline [PBS], 2 mM EDTA, and 0.5\% BSA) and stained with the following labeled antibodies: anti-CD90 PE (clone PX-7), anti-CD44 fluorescein isothiocyanate (FITC; clone OX-49), anti-major histocompatibility complex (MHC) class I PE (clone OX-18), anti-MHC class II PE (clone OX-6), anti-CD45 PE (clone OX-1), and PE and FITC isotype controls (all BD Biosciences, San Diego, CA, USA). The following unlabeled antibodies were also used: anti-CXCR4 (LS-C6307; LifeSpan BioSciences, Seattle, WA, USA), anti-VEGFR1 (ab2350; Abcam, Hartford, CT, USA), anti-CD73 (clone 5F/B9; BD Biosciences), and corresponding unlabeled isotype controls. Secondary staining of unlabeled antibodies and isotypes was performed using AlexaFluor 488, AlexaFluor PE, or AlexaFluor 633 secondary antibodies at 1:1,000 dilution (Molecular Probes, Eugene, OR, USA). Events were acquired with a FACS Canto flow cytometer (Beckman Coulter, Fullerton, CA, USA), and data were analyzed with FCS Express V3 software (De Novo software, Ontario, Canada).

\section{Karyotyping}

MDPCs were subjected to G-banding analysis (Cytogenetics Core Lab, University of Minnesota, USA) or spectral karyotyping (Laboratory of Germline Modification, Van Andel Institute, Michigan, USA).

Cytokine analysis

In vitro and in vivo cytokine concentrations were measured by multiplex cytokine analysis, according to the manufacturer's recommendations (Pierce Biotech, Rockford, IL, USA and Cytokine Core Lab, University of Maryland, Baltimore, MD, USA).

\section{Trilineage differentiation of MDPC}

MDPCs were cultured in eight-well chamber slides under conditions shown to promote tissue-specific differentiation of MAPCs into cells of all three germ cell lineages (mesodermendothelium, endoderm-hepatocytes, ectoderm-neurons) [7]. In brief, for endothelial differentiation, MDPCs were cultured at 50,000 cells per $\mathrm{cm}^{2}$ on plastic slides coated with Matrigel (BD Biosciences) in basal media with $10 \mathrm{ng} / \mathrm{ml}$ VEGF. For hepatocyte differentiation, cells were cultured at 50,000 cells per $\mathrm{cm}^{2}$ on plastic slides coated with Matrigel in MAPC basal media with $10 \mathrm{ng} / \mathrm{ml}$ fibroblast growth factor (FGF)-4 and $20 \mathrm{ng} / \mathrm{ml}$ hepatocyte growth factor (HGF). For neuronal differentiation, cells were cultured at 5,000 cells per $\mathrm{cm}^{2}$ on glass slides (BD) coated with $10 \mathrm{ng} / \mathrm{ml}$ fibronectin (BD) in Neurobasal media (Gibco) with $100 \mathrm{ng} / \mathrm{ml}$ basic FGF (bFGF) for 7 days followed by $100 \mathrm{ng} / \mathrm{ml}$ sonic hedgehog and $10 \mathrm{ng} / \mathrm{ml} \mathrm{FGF-8b}$ for 7 days. All cytokines were from R\&D. After 14 days, cells were analyzed for evidence of differentiation by real-time polymerase chain reaction (PCR) and tissue-specific immuno-fluorescence.

\section{Quantitative real-time PCR}

After differentiation, cells were lysed within chamber slides with lysis buffer (Stratagene, La Jolla, CA, USA), and ribonucleic acid (RNA) was extracted using Absolutely RNA MiniPrep Kit (Stratagene) and treated with DNase I according to the manufacturer's instructions. Real-time PCR data were normalized by measuring average cycle threshold $(\mathrm{Ct})$ between candidate genes and the GAPDH control gene. The formula $2^{\mathrm{Ct}(\text { candidate) }} / 2^{\mathrm{Ct}(\mathrm{GAPDH})}$ was used to calculate normalized ratios (NRs) for each candidate gene. NRs were then expressed as relative expression using the formula $\mathrm{NR}^{\text {(after differentiation) }} / \mathrm{NR}^{\text {(before differentiation) }}$. As a control, relative expression for each candidate gene was calculated for MDPCs cultured in normal MAPC media during the differentiation period. The following primers were used:

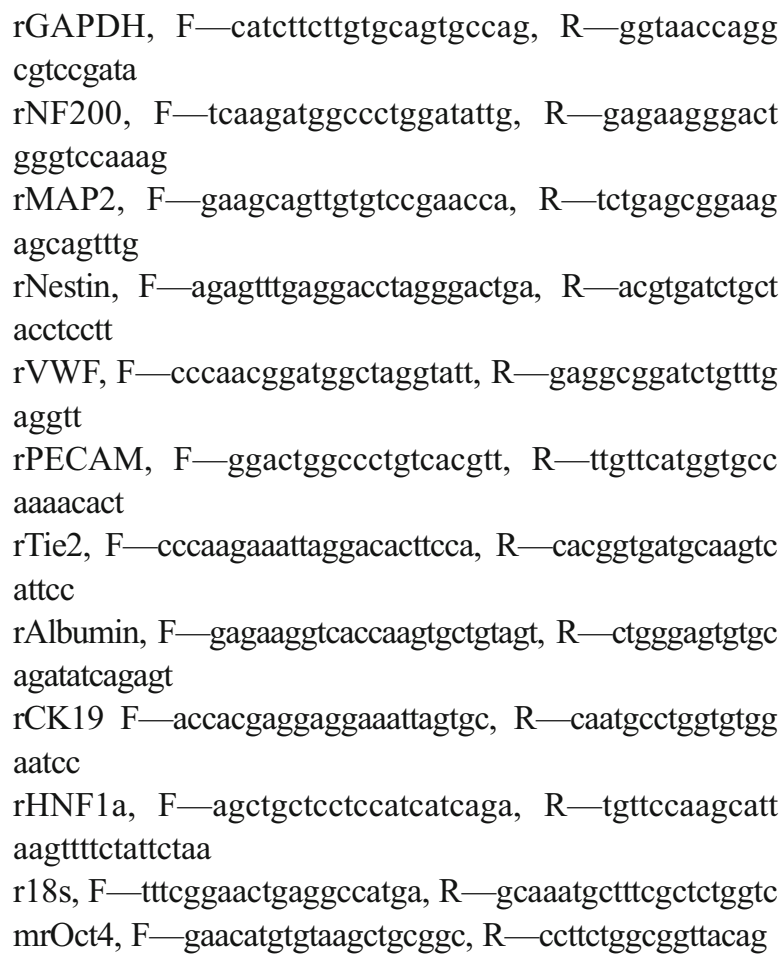

Immuno-fluorescent staining of cultured cells

After differentiation, the cells were gently rinsed with PBS and fixed with $4 \%$ para-formaldehyde for $10 \mathrm{~min}$ or methanol at $-20^{\circ} \mathrm{C}$ for $2 \mathrm{~min}$. For intracellular antigens, cells were permeabilized with $0.1 \%$ Triton- 100 for $15 \mathrm{~min}$. Antibodies used were von Willebrand factor (vWF; 0082, 
Dako, Carpentaria, CA, USA), CD31 (3A12, BD Biosciences), RECA1 (reca1, Abcam), albumin (A0001, Dako) HNF-1 (H205, Santa Cruz, Santa Cruz, CA, USA), cytokeratin 18 (Ks18.04, Chemicon), neuron-specific enolase (MAB314, Chemicon), and nestin (rat401, BD Biosciences). Secondary staining was then performed using AlexaFluor 488 or AlexaFluor 594 secondary antibodies at 1:1,000 dilution (Molecular Probes). After endothelial differentiation, the cells were incubated for $4 \mathrm{~h}$ with $1 \mu \mathrm{g} / \mathrm{ml}$ Di-labeled acetylated low-density lipoprotein (LDL; Molecular Probes).

\section{Assessment of limb perfusion}

Perfusion was measured using fluorescent microspheres (Molecular Probes). One million microspheres were injected into the left ventricular cavity over $60 \mathrm{~s}$. After injection, the adductor and gastrocnemius muscles and both kidneys were harvested and weighed. Analysis of kidney perfusion confirmed adequate mixing within the circulation and processing of the microspheres. Fluorescent microspheres were retrieved from samples using ethanolic alkaline digestion [19].

Histological and immuno-fluorescence analysis of hind limb muscles

For assessment of transplanted MDPC engraftment, samples were fixed with $2 \%$ para-formaldehyde and incubated for $12 \mathrm{~h}$ in $\mathrm{X}$ Gal reagent at $37^{\circ} \mathrm{C}$. Samples were then refixed in $10 \%$ formalin, paraffin-embedded, and cut to $5-\mu \mathrm{m}$ sections. Sections were counterstained with nuclear fast red. To enumerate the number of engrafted MDPCs, ten sections from each animal $(n=7)$ were analyzed for presence of $\mathrm{LacZ}^{+}$cells. The mean number of neurovascular bundles (NVBs) with engrafted cells was calculated for each rat along with the mean number of cells in each positively engrafted NVB. The following antibodies were used: smooth muscle alpha-actin (SMA) (SigmaAldrich, Clone A-2457, 1:4,000), anti-vWF (DAKO, 1:500), anti-proliferating cell nuclear antigen (PCNA; DAKO, 1:100), anti-CD34 (Cell applications, 1:100), antiCD11b (Clone OX-42, BD Biosciences), or isotype control. Secondary staining was then performed as described (see above). To measure capillary density, samples were snap frozen in ornithine carbamyl transferase, and 5- $\mu \mathrm{m}$ sections were cut. Sections were stained with anti-rat CD31 (TLD 3A12, BD Biosciences) to label endothelial cells. The number of $\mathrm{CD} 31^{+}$cells were counted from four randomly selected fields at a magnification of $\times 200$ from each muscle ( $n=6$ each group). Results were expressed as number of $\mathrm{CD} 31^{+}$capillaries per muscle fiber. We were unable to detect LacZ by immunohistochemistry since commercially available antibodies against LacZ did not produce specific staining (data not shown).

Monocyte depletion

Liposomal-encapsulated clodronate and control liposomes were obtained from Encapsula NanoSciences LLC (Nashville, TN, USA). Four hundred microliters of liposome solution was injected via tail vein $24 \mathrm{~h}$ before and $48 \mathrm{~h}$ after MDPC transplantation. Peripheral blood monocyte counts were performed as previously described [20].

AMD 3100

A continuous $20 \mathrm{mg} \mathrm{kg}{ }^{-1}$ week $^{-1}$ dose of AMD3100 (Sigma-Aldrich) was administered to rats with the aid of an osmotic minipump (Alzet) starting $24 \mathrm{~h}$ prior to ischemia. After 2 weeks, a total dose of $40 \mathrm{mg}$ had been delivered.

Statistical analysis

All results are expressed as mean \pm SEM. Statistical significance was evaluated with an unpaired Student's $t$ test for comparison between two groups or with analysis of variance for comparison between multiple groups using Prism 4 software (Graphpad Software, San Diego, CA, USA). A probability value of $p<0.05$ was considered significant.

\section{Results}

Multilineage differentiation potential of MDPCs

Previous studies have demonstrated that bone marrow may contain stem cells with multilineage potential. We established cultures of MDPCs from the bone marrow of Fisher 344 rats as previously described for MAPCs [7]. After over 220 population doublings (pd), the cells continued to proliferate with a stable morphology and showed no signs of senescence (Fig. 1a). Surface markers were assessed by flow cytometry after 120 and 200 pd and are shown in Fig. 1b. Costaining of MDPCs indicated that greater than 99\% were copositive for CXCR4 and VEGFR1 (Fig. 1c). In addition, MDPCs did not express Oct4 by real-time PCR (data not shown). Despite prolonged culture, the karyotype of MDPCs remained stable, although nonclonal abnormalities were identified (Fig. 1d). To establish their in vitro multipotentiality, we differentiated MDPCs into cells with the properties of three germ cell lineages under conditions similar to those described for the differentiation of MAPCs [7]. Differentiated MDPCs expressed markers for endodermal, neuroectodermal, and mesoder- 
a

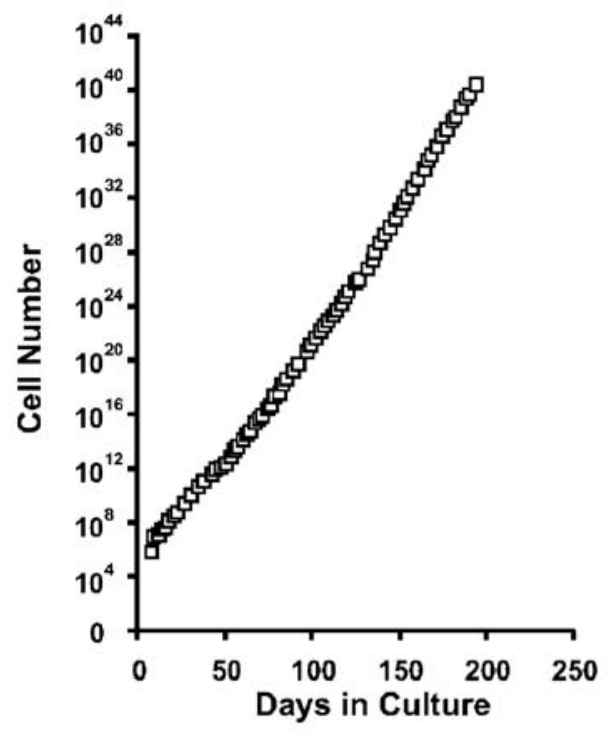

b
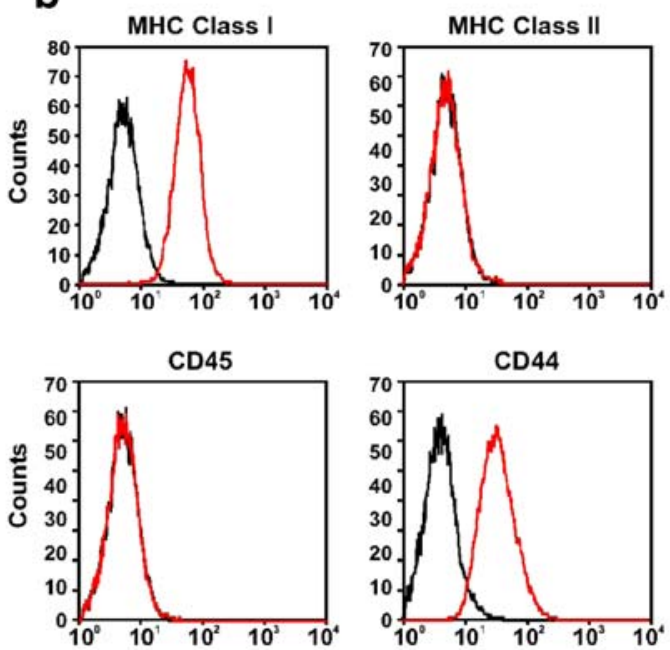

- Isotype

- Specific Antibody
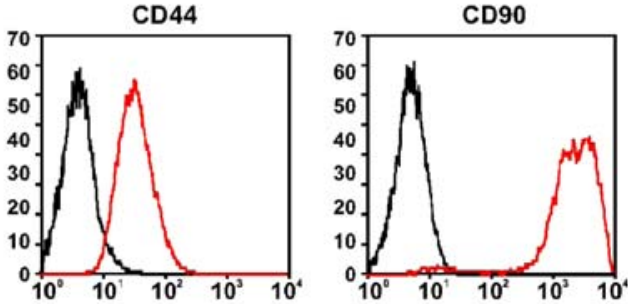

C

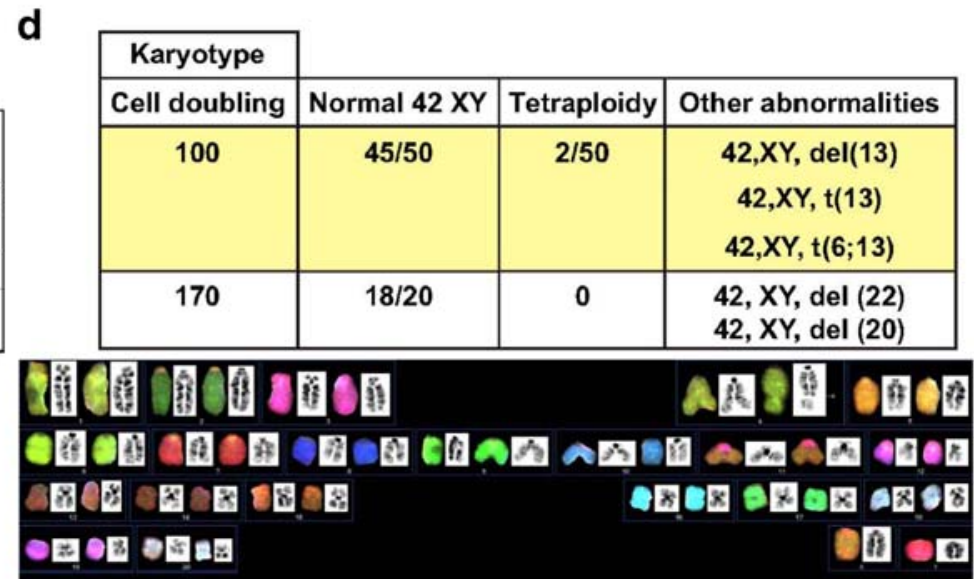

Fig. 1 Characteristics of MDPCs. a Cells were enumerated at each passage and could be maintained for over $220 \mathrm{pd}$. b MDPC surface markers. Example of MDPCs cultured for 120 pd. MDPCs were MHC class I, CD44, CD90 positive, and MHC class II, CD45, CD73 negative. c FACS plots of MDPCs using isotype control (left) or anti-

mal lineages (Fig. 2). MDPCs also underwent osteogenesis and adipogenesis (data not shown). These data suggest that MDPCs possess in vitro multipotentiality similar to MAPCs yet exhibit different surface marker and transcription factor profiles. In addition, MDPCs secrete numerous cytokines and growth factors involved in inflammation and angiogenesis as shown (Table 1).

MDPCs increase regional muscle perfusion and capillary density in a hind limb model of chronic ischemia

As MDPCs have multipotent properties in vitro, we hypothesized that MDPCs may have favorable effects in an ischemic rat hind limb model. Twenty-four hours after induction of ischemia, $10 \times 10^{6}$ MDPCs cultured for $120 \mathrm{pd}$ or PBS control were injected into the ischemic adductor muscle group. In the early phase of ischemic tissue
CXCR4 and anti-VEGFR1 antibodies (right). d Karyotype of MDPCs at 100 and $170 \mathrm{pd}$. The majority of cells had a normal karyotype of 42XY. However, isolated nonclonal tetraploidy, translocations, or deletions were seen. del Deletion, $t$ translocation

remodeling, an increase in capillary density was observed 1 week after injury (Fig. 3a). Four weeks after MDPC administration, relative whole-muscle perfusion was normalized compared to the uninjured control leg (PBS $=62 \pm$ $10 \%, \mathrm{MDPC}=102 \pm 14 \%, p<0.05$; as measured per gram of muscle; Fig. 3b).

MDPCs engraft into the neurovascular bundle of ischemic but not normally perfused, sham-operated muscles

To track the long-term engraftment and fate of MDPCs in vivo, MDPCs were stably transduced with a $\beta$-Galexpressing retrovirus. Four weeks after injection of MDPCs, tissues were harvested and stained with X-Gal reagent to identify LacZ-expressing cells. Significant engraftment of MDPCs was detected when injected into ischemic muscles (Fig. 4a). Although MDPCs were seen 


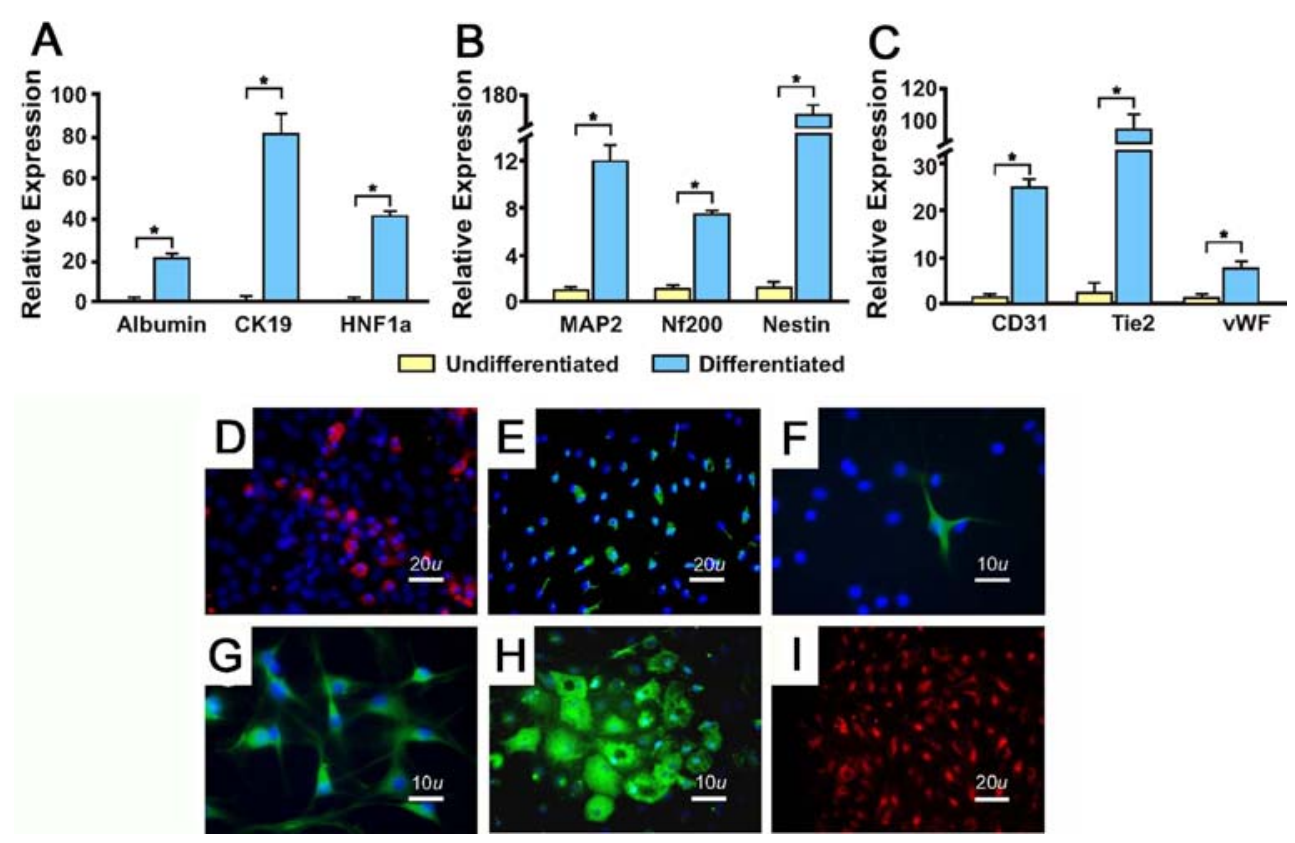

Fig. 2 In vitro differentiation of MDPCs into endodermal-, neuroectodermal-, and endothelial-like cells. a-c 14 days after differentiation, cell lysates were analyzed by real-time PCR for tissue-specific gene expression. a Endoderm differentiation: cytokeratin 19, $81 \pm$ 21.5-fold increase over baseline, albumin, $21 \pm 2.2$-fold increase, and hepatocyte nuclear factor 1 alpha $(H N F 1 a), 41 \pm 4.9$-fold increase. b Neuroectoderm differentiation: MAP2, $12 \pm 1.3$-fold increase, NF200, $7 \pm 0.2$ fold increase, and nestin, $131 \pm 9.2$-fold increase. c Mesodermal differentiation; CD31, 25 \pm 4.1 -fold increase, Tie2, $85 \pm 10.0$-fold

along needle tracks and occasionally scattered in between the muscle fibers, MDPCs were predominantly localized around the NVBs and specifically concentrated around arterioles (Fig. 4b). Within the ischemic adductor muscles, $19 \pm 5 \%$ of NVBs were associated with $\mathrm{LacZ}^{+}$cells. $\mathrm{LacZ}^{+}$ NVBs contained $16 \pm 7 \mathrm{LacZ}^{+}$cells. However, when MDPCs were injected into normally perfused shamoperated muscle, only the occasional cell remained after 4 weeks. Less than $1 \%$ of NVB in sham-operated mice with normally perfused muscles had LacZ $\mathrm{Z}^{+}$cells, and there were only one to four cells associated with them (Fig. 4c). This indicates that ischemia may provide a permissive state for

Table 1 In vitro cytokine levels

\begin{tabular}{lc}
\hline Cytokines & $\begin{array}{c}\text { Concentration } \\
\left(\mathrm{pg} / 10^{5} / 24 \mathrm{~h}\right)\end{array}$ \\
\hline MCP-1 & $13,982 \pm 1721$ \\
Gro/KC & $1,900 \pm 183$ \\
SDF-1 & $160 \pm 80$ \\
MIP-2 & $56 \pm 6.5$ \\
MIP-3 & $30 \pm 15$ \\
bFGF & $26 \pm 1$ \\
VEGF & $14 \pm 1$ \\
HGF & $6 \pm 1$ \\
\hline
\end{tabular}

increase, and vWF, 7.2 \pm 1.9 -fold increase. Yellow bars indicate cells cultured in normal media, and blue bars indicate tissue specific differentiation media. Asterisk, $p<0.001$. d-i Immuno-fluorescent assessment of MDPCs differentiated in vitro toward $\mathbf{d}$, e endodermal lineages, stained with $\mathbf{d}$ anti-albumin and $\mathbf{e}$ anti-cytokeratin 19. f, g Neuroectodermal lineages, stained with $\mathbf{f}$ anti-nestin and $\mathbf{g}$ anti-NSE. $\mathbf{h}$, $\mathbf{i}$ Endothelial-like cells, stained with $\mathbf{h}$ anti-RECA1 and $\mathbf{i}$ assessed for Di-labeled acetylated LDL uptake

VEGFR $1^{+}$CXCR $4^{+}$MDPCs to localize and concentrate in the NVBs.

MDPC do not differentiate into endothelial or smooth muscle cells in ischemic muscle

$\mathrm{LacZ}^{+}$MDPCs were mostly located in the adventitialmedial border zone of arterioles and could not be detected at the luminal side. Although we did not attempt to differentiate MDPCs into smooth muscle cells in vitro, the engraftment of MDPCs into the adventitial-medial border of arterioles suggested that they may have adopted a smooth muscle phenotype. Therefore, sections from muscles harvested 4 weeks after cell injection were counterstained with an antibody against SMA. However, engrafted cells did not stain for SMA (Fig. 4d). In addition, engrafted MDPCs did not stain for vWF (data not shown). This suggests that MDPCs did not differentiate into smooth muscle or endothelial cells. Furthermore, transplanted MDPCs stained negative for calponin, NG2, and PDGFR$\beta$ (data not shown), indicating, in conjunction with their anatomical location, that they did not become pericytes. Although MDPCs did not express CD34, engrafted cells could be found in close proximity to adventitial CD $34^{+}$ cells. Interestingly, previous reports have suggested that 

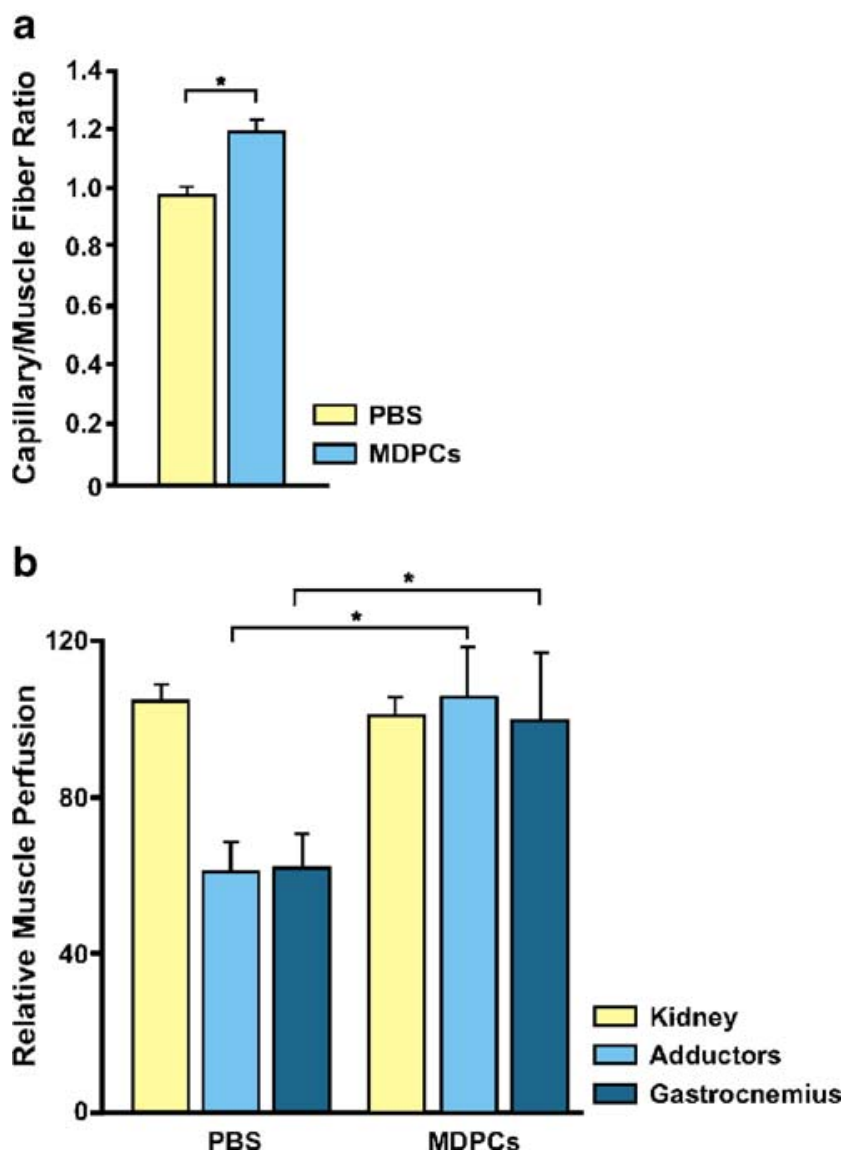

Fig. 3 Assessment of hind limb muscle perfusion after MDPC transplantation. a MDPCs increased capillary density of ischemic muscle. One week after MDPC transplantation, sections were stained for $\mathrm{CD} 31$. The number of $\mathrm{CD} 31^{+}$cells per muscle fiber was enumerated and is presented as capillary/muscle fiber ratio. Asterisk, $p<0.05$. b MDPCs increased perfusion of ischemic muscle. $1 \times 10^{6}$ green-yellow fluorescent microspheres were injected into the left ventricle 4 weeks after MDPC or PBS control transplantation. Results are expressed as relative fluorescence of ischemic limb/fluorescence of normally perfused limb standardized by weight of tissue. Asterisk, $p<0.05$

$\mathrm{CD} 34^{+}$cells located at the adventitial-medial border zone may participate in a vascular progenitor cell niche [21]. $\mathrm{LacZ}^{+}$skeletal muscle fibers were not observed in any animal.

MDPCs modulate vascular remodeling through paracrine mechanisms

Because transplanted MDPCs increased the capillary density and perfusion of ischemic muscles but did not differentiate into vascular structures, we examined their ability to modulate vascular wound repair in vivo. Five and 14 days after injection of $10 \times 10^{6}$ MDPCs or PBS into ischemic limbs, muscles were harvested, homogenized, and submitted to cytokine analysis. At 5 days, SDF-1, mono- cyte chemotactic protein-1 (MCP-1), and macrophageinflammatory protein-2 (MIP-2) levels were all found to be significantly elevated compared to limbs injected with PBS (Table 2). Fourteen days after transplantation, there was no difference in cytokine levels between animals injected with MDPCs or PBS (data not shown). This demonstrates that MDPCs modulate local cytokine levels during the early phase of vascular remodeling.

Importantly, local SDF-1 facilitates the retention of $\mathrm{CD} 11 \mathrm{~b}^{+}$myelo-monocytic cells at the site of wound repair. These cells are known to be necessary for successful balanced vascular healing [17]. Therefore, we elected to characterize the spatial relationship between MDPCs, infiltrating $\mathrm{CD}_{11} \mathrm{~b}^{+}$cells, and proliferating endothelial cells. We performed immunohistochemistry on serial sections 1 week after injury and found that these cells shared a close spatial relationship during the early phase of wound repair (Fig. 5a). Next, we explored if MDPC administration with subsequent increased local cytokine levels modulated the number of NVB-associated $\mathrm{CD}_{11 \mathrm{~b}^{+}}$myelo-monocytic cells. We determined the percentage of $1 \mathrm{acZ} \mathrm{Z}^{-} \mathrm{CD} 11 \mathrm{~b}^{+}$cells at the NVBs on muscle sections of MDPC-injected animals and compared them to PBS-injected control animals at 1 week after injury $\left(\mathrm{CD} 11 \mathrm{~b}^{+}\right.$cells; MDPCs $=33.6 \pm 4.4 \%$ vs. PBS $=12.0 \pm 1.8 \%$; $p<0.005$; Fig. $5 b$ ). By 4 weeks postinjury, all inflammatory cell infiltrates had resolved, and $\mathrm{CD}_{11 \mathrm{~b}^{+}}$cells could no longer be identified (data not shown). We suggest that in addition to endogenous recruitment mechanisms, MDPC administration led to increased local cytokine levels, thereby concentrating $\mathrm{CD}_{11} \mathrm{~b}^{+}$cells at the NVB in the acutely ischemic tissue. However, while SDF-1 is known to play an important role in the localization of $\mathrm{CD} 1 \mathrm{~b}^{+}$cells during vascular remodeling, it was not clear if SDF-1 has a similar function in the retention of transplanted MDPCs. To further explore the mechanism leading to the localization of MDPCs at the adventitial-medial border zone, we blocked SDF-1 function by inhibition of its receptor CXCR4 with AMD3100, a CXCR4-specific receptor antagonist. These experiments revealed that the adventitial-medial border zone localization of MDPCs requires signaling through CXCR4, as AMD3100 virtually eliminated the retention of these cells 4 weeks after transplantation (Fig. 5c). We also observed that in animals receiving MDPCs, AMD3100 administration led to a decrease in the number of adventitial $\mathrm{CD} 11 \mathrm{~b}^{+}$cells $\left(\mathrm{CD} 11 \mathrm{~b}^{+}\right.$cells: $\mathrm{MDPCs}$ only $=32.6 \pm 3.1 \%$; MDPCs + AMD3100 $=6.8 \pm 2.7 \% ; p<0.0005)$ and a reduced number of proliferating $\mathrm{CD} 31^{+}$endothelial cells $\left(\mathrm{CD} 31^{+} / \mathrm{BrdU}^{+}\right.$ cells $\left[\%\right.$ total $\mathrm{CD} 31^{+}$cells]: MDPCs only $=21.0 \pm 3.2$; MDPCs + AMD3100 $=11.3 \pm 1.5 ; p<0.05$; Fig. $5 d$ ). Furthermore, in control animals that received AMD3100 without MDPCs, we confirmed that when compared to animals receiving MDPCs (with or without AMD3100), the known 
Fig. 4 Fate of MDPCs after transplantation. a, b MDPCs engrafted into the adventitialmedial border of arterioles in significant numbers. Occasional cells were also seen between muscles fibers. a Muscle crosssection demonstrating engraftment of MDPCs. b Enlarged view of arteriole with engrafted MDPCs. c Very few LacZ $Z^{+}$ MDPCs were identified after injection into normally perfused muscles. d MDPCs do not differentiate into smooth muscle cells. Sections from ischemic hind limbs injected with MDPCs were stained with SMA. Despite their engraftment at the adventitial-medial border of arterioles, $\mathrm{LacZ}^{+}$MDPCs (pseudocolored green) were negative for SMA (red), indicating that they had not differentiated into smooth muscle cells. No MDPCs were found lining the lumen of vessels. e MDPCs and CD34 $4^{+}$cells (red) were found in close proximity at the adventitial-medial border zone

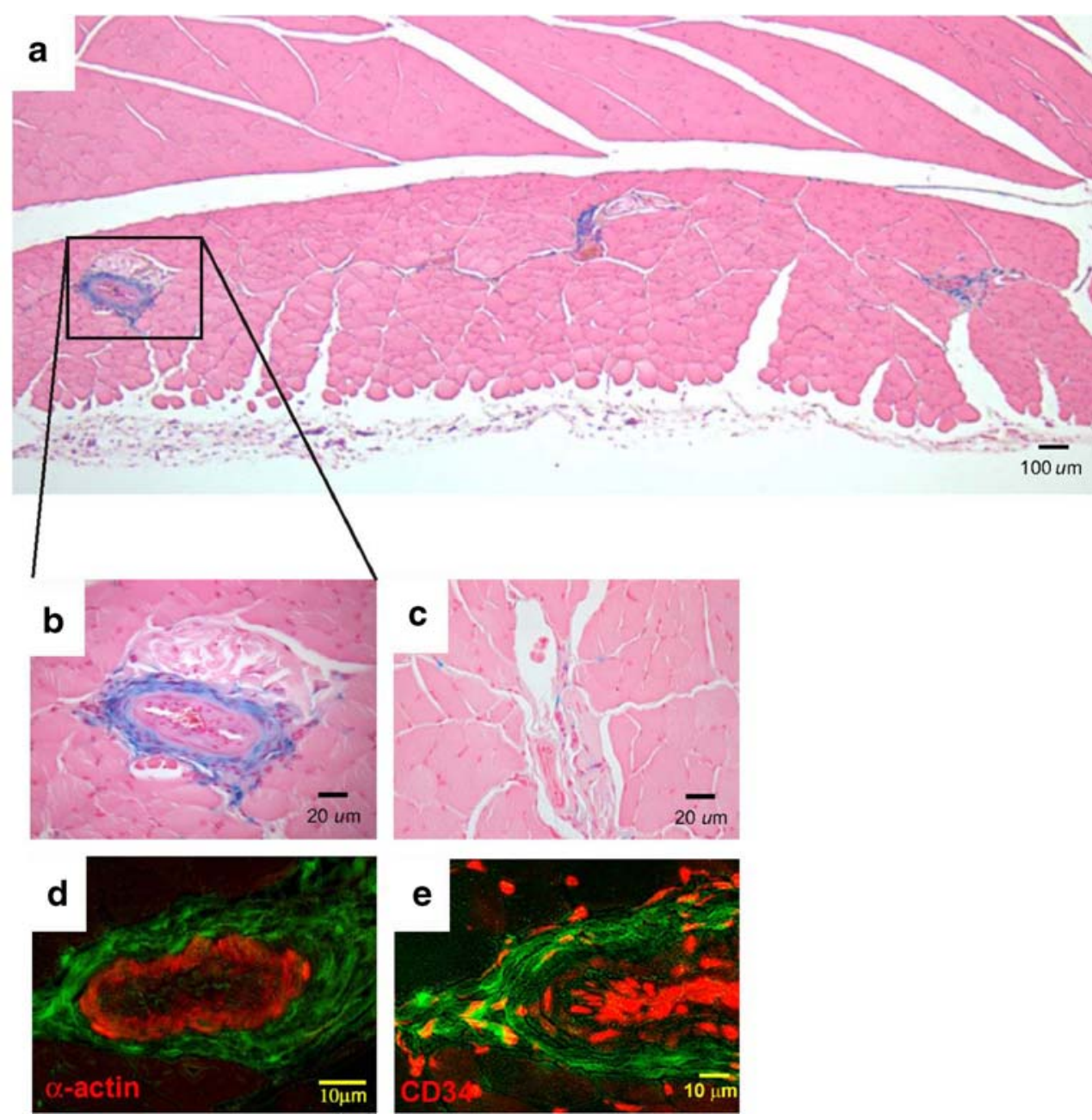

bone marrow-mobilizing effects of AMD3100 did not enhance CD11b ${ }^{+}$cell infiltration (Fig. 5d).

Finally, we undertook to determine the degree of contribution of recruited myelo-monocytic cells to the enhanced local cytokine levels after MDPC transplantation. Thus, monocytes were depleted by liposomal-encapsulated clodronate administration, and local tissue cytokine concentrations were determined 5 days after MDPC transplantation. While monocyte depletion decreased local MIP-2 levels, we found that local levels of SDF-1 and MCP-1 were not affected (Fig. 6).

Table 2 In vivo cytokine levels

PBS (pg/g tissue) MDPCs (pg/g tissue) Fold $\Delta p$ value

\begin{tabular}{lccll}
\hline MCP-1 & $1,854 \pm 496$ & $7,046 \pm 367$ & 3.1 & 0.001 \\
SDF-1 & $161 \pm 58$ & $969 \pm 89$ & 6.0 & 0.002 \\
MIP-2 & $10.4 \pm 0.5$ & $88 \pm 20$ & 8.4 & 0.02 \\
Gro/KC & $70 \pm 19$ & $123 \pm 58$ & 1.8 & 0.44 \\
bFGF & $3,298 \pm 2041$ & $1,663 \pm 427$ & 0.5 & 0.48 \\
HGF & $797 \pm 77$ & $616 \pm 232$ & 0.8 & 0.66 \\
VEGF & $729 \pm 23$ & $907 \pm 66$ & 1.1 & 0.09 \\
\hline
\end{tabular}

\section{Discussion}

In the present study, we investigated the effects of bone marrow-derived MDPCs with in vitro pluripotent properties in a hind limb model of ischemia. We demonstrated that although MDPCs can be differentiated in vitro, they do not differentiate in vivo into vascular cells despite engrafting and improving perfusion. We speculate that the improvement in perfusion results from the secretion of inflammatory and angiogenic cytokines through paracrine mechanisms modulating the immune response and vascular remodeling.

Employing methods similar to those used to isolate MAPCs [7], we isolated a mixed culture of cells that appear to contain pluripotent progenitors. Indeed, our finding that MDPCs (or their progeny) elaborate cytokines in the setting of rat hind limb ischemia is entirely consistent with the results obtained when MAPCs were administered to mice using a similar experimental model [22]. Although, in contrast to our study, we note that in the MAPC study, a very limited degree of progenitor cell differentiation into both endothelial and smooth muscle cells was also observed 
A

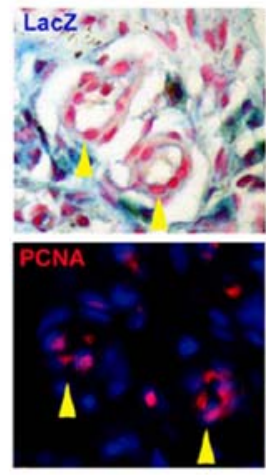

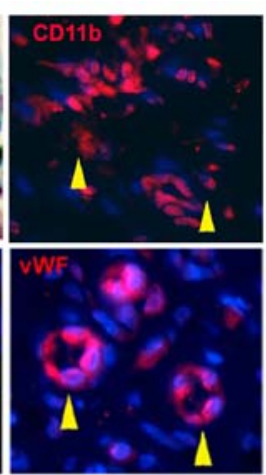

B

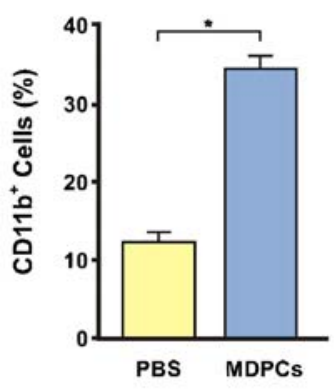

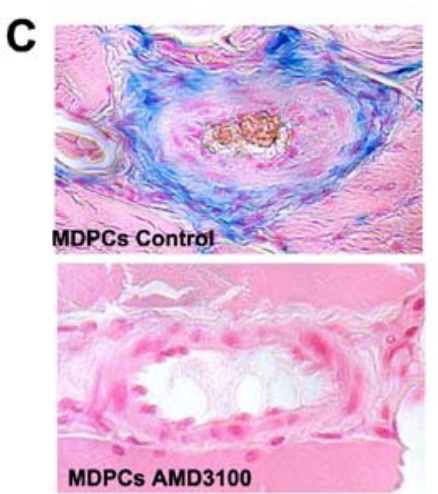

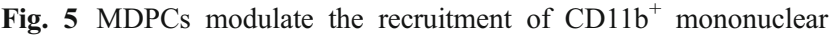
cells to the NVBs. a Serial section staining 1 week after injury showing the spatial relationship between $\mathrm{CD} 11 b^{+}$cells, $\mathrm{LacZ}^{+}$ MDPCs, and $\mathrm{vWF}^{+}$endothelial cells. PCNA was used as a proliferation marker. Yellow arrowheads indicate arterioles. b Relative numbers of $\mathrm{CD}_{11 \mathrm{~b}^{+}} \mathrm{LacZ}^{-}$cells were determined at the NVBs on MDPC-transplanted muscle sections (blue bar) and compared to

[22]. However, we did not undertake a single-cell cloning step as previously described for MAPCs [7] and more recently for bone marrow stem cells [10], as we found that in rodents, single-cell cloning tends to select for cytogenetically abnormal cells. Importantly, MDPCs maintained a stable karyotype when analyzed by G-banding or spectral karyotyping. As we did not document any clonal abnormalities in MDPC cultures (defined as being present in more than two cells), the lines were considered normal according to the International System for Human Cytogenetic Nomenclature (ISCN 1995) [23].

MDPCs express MHC class I, CD44, and CD90 similar to MSCs but do not express CD73 as described for MSCs [24]. We were able to upregulate tissue-specific antigens of the ectoderm, endoderm, and mesoderm as measured by both reverse transcriptase PCR and by immuno-fluorescence and similar to the original descriptions of MAPCs and of pMultistem recently described by Zeng et al. [9, 25].

In order to investigate the potential of MDPCs to improve the perfusion of an ischemic tissue, we developed a hind limb ischemia model to allow the syngeneic transplantation of cells. We injected 10 million MDPCs into the controls (yellow bar) at 1 week after injury. Asterisk, $p<0.005$. c Serial section staining 4 weeks after injury revealed that recruitment and/or retention of MDPCs to the adventitial-medial border zone was blocked by AMD3100, an antagonist of the SDF-1 receptor CXCR4. d One week after injury and following MDPC therapy, AMD3100 administration led to a decrease in both $\mathrm{CD} 11 \mathrm{~b}^{+}$cell recruitment and capillary density. Asterisk, $p<0.05$; double asterisk, $p<0.0005$

ischemic adductor muscle, a dose that is similar to previous studies in rats $[26,27]$. This led to an early but modest increase in capillary density, with a more marked augmentation in perfusion levels by 4 weeks after the ischemic insult. We speculate that transplanted MDPCs may have had a progressive effect during the healing process, thereby accounting for apparently greater magnitude of enhanced perfusion at 4 weeks, compared to the effects on capillary density seen at 1 week.

We next studied the fate of MDPCs 4 weeks after transplantation. MDPCs selectively engrafted into the NVB of ischemic muscles, primarily within the adventitia of small vessels and arterioles. Only the occasional $\mathrm{LacZ}^{+}$cell was detected after injection into normally perfused muscles, indicating that MDPCs selectively engraft into ischemic limbs. As MDPCs express the VEGF receptor VEGFR1 and the SDF-1 chemokine receptor CXCR4, we speculated that these signaling systems may be involved in the selective engraftment of MDPCs, in a manner similar to the physiological engraftment of bone marrow-derived cells. We found that inhibition of SDF-1 function with the CXCR4-specific receptor antagonist AMD3100 inhibited 
Fig. 6 Monocyte depletion decreases MIP-2 levels after MDPC transplantation in the rat ischemic hind limb. a Monocytes were significantly depleted by administration of liposomal encapsulated clodronate (triangles) compared to control liposomes (squares) during the first 6 days after induction of hind limb ischemia. LI liposome injection; triple asterisk, $p<$ 0.0001. b Local tissue cytokine concentrations were determined 5 days after MDPC transplantation. Monocyte depletion ( $d e p l)$ significantly decreased local MIP-2 levels in ischemic hind limbs compared to controls (Co). Monocyte depletion did not influence local SDF-1 or MCP-1 levels. Double asterisk, $p<0.001$

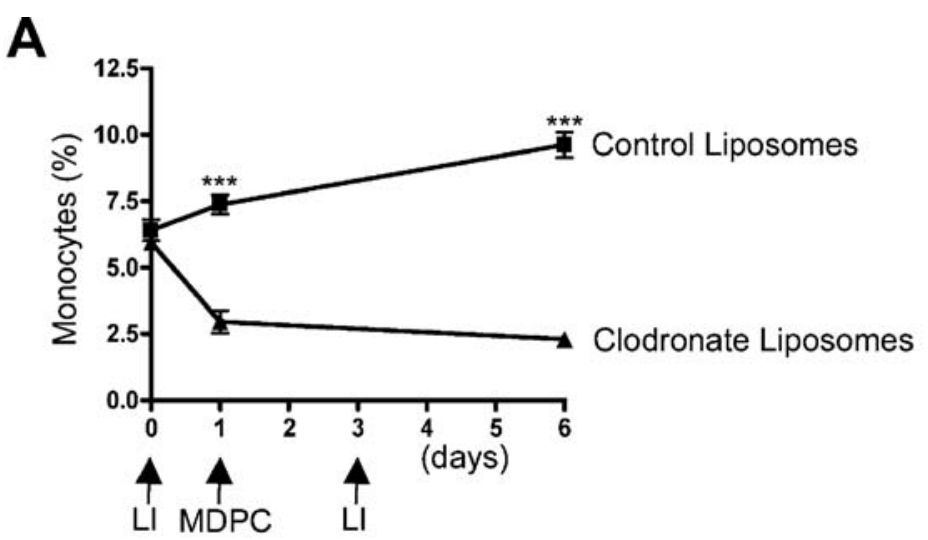

B
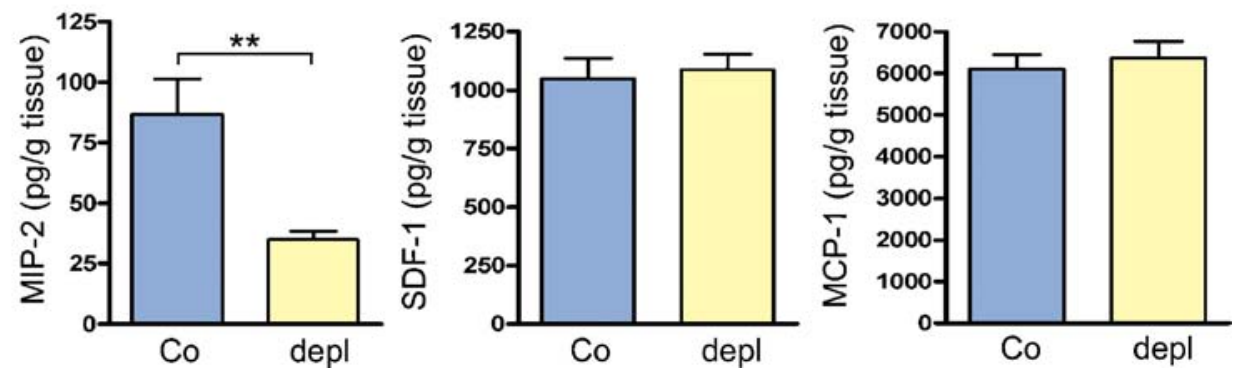

the engraftment of MDPCs. Despite persistent engraftment 4 weeks after transplantation, we did not detect any MDPCs (or their progeny) with either an endothelial or smooth muscle cell phenotype. This would indicate that any increase in perfusion was more likely the result of paracrine effects rather than MDPCs forming de novo blood vessels. It has been suggested that the media/adventitia boundary of the vascular wall may be a source of vascular progenitor cells capable of postnatal vasculogenesis [21, 28]. Since engrafted MDPCs were located in close proximity to $\mathrm{CD} 34^{+}$cells at the adventitial-medial border zone, it is possible that MDPCs may have selectively homed to this niche.

In keeping with other studies of bone marrow-derived cells [13, 22, 29-31], we demonstrated that MDPCs also secrete multiple cytokines in vitro that are known to modulate inflammatory and angiogenic processes. These include members of the chemokine family, such as MCP-1 and SDF-1, as well as known angiogenic cytokines such as VEGF, bFGF, and HGF. In a similar study, Kinnard et al. [29] demonstrated that transplanted MSCs increase local production of bFGF and VEGF. They also suggested that these two factors might directly enhance endothelial and vascular smooth muscle cell proliferation in a mouse hind limb model. We extended this model and suggest that transplanted cells also modulate the local inflammatory response to injury. We demonstrated that in vivo, SDF-1, MCP-1, and MIP-2 are increased 5 days after transplantation of MDPCs and that recruited myelo-monocytic cells contribute to the enhanced levels of MIP-2.
SDF-1 is a chemokine that has been shown to be transiently increased in ischemic muscles and which is important for the homing of cells via the chemokine receptor CXCR4 [32-34]. Local VEGF production in ischemic tissues is believed to be the key cytokine controlling SDF-1 release [17, 18]. Vascular myofibroblasts secrete VEGF, which subsequently induces the expression of SDF-1. VEGF recruits circulating bone marrow-derived cells, predominantly myeloid mononuclear cells, which are then retained in close proximity to angiogenic vessels. Retention is mediated via the chemokine receptor CXCR4 interacting with locally produced SDF-1. These retained myeloid cells then enhance the local proliferation of endothelial cells via the secretion of proangiogenic cytokines [17]. Several studies have shown that the recruitment of monocytes to ischemic tissues, without incorporation or differentiation into vascular lineages, plays an important role in angiogenesis $[35,36]$. Increasing SDF-1 expression in ischemic tissues with cell transplantation is likely to augment the physiological recruitment, homing, and trapping of bone marrow-derived cells, as will increasing MCP1 expression [37]. The recruitment of myeloid cells by MDPCs is likely to further improve perfusion via the stimulation of local endothelial cells [17, 18]. We found that ischemic muscles produced elevated levels of SDF-1 and VEGF. As MDPCs also express VEGFR1 and CXCR4, the recruitment and retention of MDPCs to the adventitialmedial border zone of blood vessels may also be mediated via the VEGF-SDF-1 system in a manner similar to the recruitment of myeloid cells $[13,17]$. Indeed, inhibition of 
SDF-1/CXCR4 function by AMD3100, a CXCR4-specific receptor antagonist, dramatically reduced vascular MDPC retention.

In summary, our findings indicate that MDPCs may be recruited to the adventitial-medial border zone of vessels within ischemic tissue by VEGF and/or SDF-1. Increased levels of SDF-1 and other cytokines/chemokines then trap additional $\mathrm{CD}_{1} 1 \mathrm{~b}^{+}$mononuclear cells at the site of tissue repair. The augmented inflammatory response to ischemic tissue damage enhances capillary density and tissue perfusion. An understanding of these complex interactions between transplanted, local inflammatory, and vascular cells constitutes a critical platform for the successful implementation of clinical cell therapy.

Acknowledgments These studies were supported by the NHLBI Division of Intramural Research. We thank the Laboratory of Animal Medicine and Surgery and Robin Schwartzbeck (NIH-NHLBI) for their assistance with the transgenic mice, Caroline Graham (NHLBI) for technical assistance, Catherine Verfaillie (Stem Cell Institute, University of Minnesota) for technical support and advice, and Donald Orlic (NHLBI) for comments and critical reviewing of the manuscript.

Open Access This article is distributed under the terms of the Creative Commons Attribution Noncommercial License which permits any noncommercial use, distribution, and reproduction in any medium, provided the original author(s) and source are credited.

\section{References}

1. Asahara T, Murohara T, Sullivan A, Silver M, van der Zee R, Li T, Witzenbichler B, Schatteman G, Isner JM (1997) Isolation of putative progenitor endothelial cells for angiogenesis. Science 275:964-967

2. Orlic D, Kajstura J, Chimenti S, Limana F, Jakoniuk I, Quaini F, Nadal-Ginard B, Bodine DM, Leri A, Anversa P (2001) Mobilized bone marrow cells repair the infarcted heart, improving function and survival. Proc Natl Acad Sci USA 98:10344-10349

3. Galmiche MC, Koteliansky VE, Briere J, Herve P, Charbord P (1993) Stromal cells from human long-term marrow cultures are mesenchymal cells that differentiate following a vascular smooth muscle differentiation pathway. Blood 82:66-76

4. Assmus B, Honold J, Schachinger V, Britten MB, Fischer-Rasokat U, Lehmann R, Teupe C, Pistorius K, Martin H, Abolmaali ND, Tonn T, Dimmeler S, Zeiher AM (2006) Transcoronary transplantation of progenitor cells after myocardial infarction. $\mathrm{N}$ Engl $\mathrm{J}$ Med 355:1222-1232

5. Schachinger V, Erbs S, Elsasser A, Haberbosch W, Hambrecht R, Holschermann H, Yu J, Corti R, Mathey DG, Hamm CW, Suselbeck T, Assmus B, Tonn T, Dimmeler S, Zeiher AM (2006) Intracoronary bone marrow-derived progenitor cells in acute myocardial infarction. N Engl J Med 355:1210-1221

6. Lunde K, Solheim S, Aakhus S, Arnesen H, Abdelnoor M, Egeland T, Endresen K, Ilebekk A, Mangschau A, Fjeld JG, Smith HJ, Taraldsrud E, Grogaard HK, Bjornerheim R, Brekke M, Muller C, Hopp E, Ragnarsson A, Brinchmann JE, Forfang K (2006) Intracoronary injection of mononuclear bone marrow cells in acute myocardial infarction. N Engl J Med 355:1199-1209
7. Jiang Y, Jahagirdar BN, Reinhardt RL, Schwartz RE, Keene CD, Ortiz-Gonzalez XR, Reyes M, Lenvik T, Lund T, Blackstad M, Du J, Aldrich S, Lisberg A, Low WC, Largaespada DA, Verfaillie CM (2002) Pluripotency of mesenchymal stem cells derived from adult marrow. Nature 418:41-49

8. Kogler G, Sensken S, Airey JA, Trapp T, Muschen M, Feldhahn N, Liedtke S, Sorg RV, Fischer J, Rosenbaum C, Greschat S, Knipper A, Bender J, Degistirici O, Gao J, Caplan AI, Colletti EJ, Almeida-Porada G, Muller HW, Zanjani E, Wernet P (2004) A new human somatic stem cell from placental cord blood with intrinsic pluripotent differentiation potential. J Exp Med 200: $123-135$

9. Jiang Y, Vaessen B, Lenvik T, Blackstad M, Reyes M, Verfaillie CM (2002) Multipotent progenitor cells can be isolated from postnatal murine bone marrow, muscle, and brain. Exp Hematol 30:896-904

10. Yoon YS, Wecker A, Heyd L, Park JS, Tkebuchava T, Kusano K, Hanley A, Scadova H, Qin G, Cha DH, Johnson KL, Aikawa R, Asahara T, Losordo DW (2005) Clonally expanded novel multipotent stem cells from human bone marrow regenerate myocardium after myocardial infarction. J Clin Invest 115:326-338

11. O’Neill TJ, Wamhoff BR, Owens GK, Skalak TC (2005) Mobilization of bone marrow-derived cells enhances the angiogenic response to hypoxia without transdifferentiation into endothelial cells. Circ Res 97:1027-1035

12. Alvarez-Dolado M, Pardal R, Garcia-Verdugo JM, Fike JR, Lee HO, Pfeffer K, Lois C, Morrison SJ, Alvarez-Buylla A (2003) Fusion of bone-marrow-derived cells with Purkinje neurons, cardiomyocytes and hepatocytes. Nature 425:968-973

13. Ziegelhoeffer T, Fernandez B, Kostin S, Heil M, Voswinckel R, Helisch A, Schaper W (2004) Bone marrow-derived cells do not incorporate into the adult growing vasculature. Circ Res 94:230-238

14. Tang YL, Zhao Q, Qin X, Shen L, Cheng L, Ge J, Phillips MI (2005) Paracrine action enhances the effects of autologous mesenchymal stem cell transplantation on vascular regeneration in rat model of myocardial infarction. Ann Thorac Surg 80:229236 discussion 236-227

15. Caplan AI, Dennis JE (2006) Mesenchymal stem cells as trophic mediators. J Cell Biochem 98:1076-1084

16. Van Overstraeten-Schlogel N, Beguin Y, Gothot A (2006) Role of stromal-derived factor-1 in the hematopoietic-supporting activity of human mesenchymal stem cells. Eur J Haematol 76:488-493

17. Grunewald M, Avraham I, Dor Y, Bachar-Lustig E, Itin A, Yung S, Chimenti S, Landsman L, Abramovitch R, Keshet E (2006) VEGF-induced adult neovascularization: recruitment, retention, and role of accessory cells. Cell 124:175-189

18. Jin DK, Shido K, Kopp HG, Petit I, Shmelkov SV, Young LM, Hooper AT, Amano H, Avecilla ST, Heissig B, Hattori K, Zhang F, Hicklin DJ, Wu Y, Zhu Z, Dunn A, Salari H, Werb Z, Hackett NR, Crystal RG, Lyden D, Rafii S (2006) Cytokine-mediated deployment of SDF-1 induces revascularization through recruitment of CXCR4+ hemangiocytes. Nat Med 12:557-567

19. Van Oosterhout MF, Willigers HM, Reneman RS, Prinzen FW (1995) Fluorescent microspheres to measure organ perfusion: validation of a simplified sample processing technique. Am J Physiol 269:H725-H733

20. Olive M, Mellad JA, Beltran LE, Ma M, Cimato T, Noguchi AC, San H, Childs R, Kovacic JC, Boehm M (2008) p21 modulates arterial wound repair through the stromal cell-derived factor-1/ CXCR4 axis in mice. J Clin Invest 118:2050-2061

21. Zengin E, Chalajour F, Gehling UM, Ito WD, Treede H, Lauke H, Weil J, Reichenspurner H, Kilic N, Ergun S (2006) Vascular wall resident progenitor cells: a source for postnatal vasculogenesis. Development 133:1543-1551

22. Aranguren XL, McCue JD, Hendrickx B, Zhu XH, Du F, Chen E, Pelacho B, Penuelas I, Abizanda G, Uriz M, Frommer SA, Ross 
JJ, Schroeder BA, Seaborn MS, Adney JR, Hagenbrock J, Harris NH, Zhang Y, Zhang X, Nelson-Holte MH, Jiang Y, Billiau AD, Chen W, Prosper F, Verfaillie CM, Luttun A (2008) Multipotent adult progenitor cells sustain function of ischemic limbs in mice. $\mathrm{J}$ Clin Invest 118:505-514

23. Mitelman F (1995) ISCN 1995: an international system for human cytogenetic nomenclature (1995): recommendations of the International Standing Committee on Human Cytogenetic Nomenclature, Memphis, Tenn., USA, October 9-13, 1994. Karger, Basel

24. Pittenger MF, Mackay AM, Beck SC, Jaiswal RK, Douglas R, Mosca JD, Moorman MA, Simonetti DW, Craig S, Marshak DR (1999) Multilineage potential of adult human mesenchymal stem cells. Science 284:143-147

25. Zeng L, Hu Q, Wang X, Mansoor A, Lee J, Feygin J, Zhang G, Suntharalingam P, Boozer S, Mhashilkar A, Panetta CJ, Swingen C, Deans R, From AH, Bache RJ, Verfaillie CM, Zhang J (2007) Bioenergetic and functional consequences of bone marrowderived multipotent progenitor cell transplantation in hearts with postinfarction left ventricular remodeling. Circulation 115: $1866-1875$

26. Iwase T, Nagaya N, Fujii T, Itoh T, Murakami S, Matsumoto T, Kangawa K, Kitamura S (2005) Comparison of angiogenic potency between mesenchymal stem cells and mononuclear cells in a rat model of hindlimb ischemia. Cardiovasc Res 66: 543-551

27. Iba O, Matsubara H, Nozawa Y, Fujiyama S, Amano K, Mori Y, Kojima H, Iwasaka T (2002) Angiogenesis by implantation of peripheral blood mononuclear cells and platelets into ischemic limbs. Circulation 106:2019-2025

28. Kovacic JC, Boehm M (2008) Resident vascular progenitor cells: an emerging role for non-terminally differentiated vessel-resident cells in vascular biology. Stem Cell Res (in press). doi:10.1016/j. scr.2008.05.005

29. Kinnaird T, Stabile E, Burnett MS, Shou M, Lee CW, Barr S, Fuchs S, Epstein SE (2004) Local delivery of marrow-derived stromal cells augments collateral perfusion through paracrine mechanisms. Circulation 109:1543-1549

30. Gnecchi M, He H, Liang OD, Melo LG, Morello F, Mu H, Noiseux N, Zhang L, Pratt RE, Ingwall JS, Dzau VJ (2005)
Paracrine action accounts for marked protection of ischemic heart by Akt-modified mesenchymal stem cells. Nat Med 11:367368

31. Mangi AA, Noiseux N, Kong D, He H, Rezvani M, Ingwall JS, Dzau VJ (2003) Mesenchymal stem cells modified with Akt prevent remodeling and restore performance of infarcted hearts. Nat Med 9:1195-1201

32. Kahn J, Byk T, Jansson-Sjostrand L, Petit I, Shivtiel S, Nagler A, Hardan I, Deutsch V, Gazit Z, Gazit D, Karlsson S, Lapidot T (2004) Overexpression of CXCR4 on human CD34+ progenitors increases their proliferation, migration, and NOD/SCID repopulation. Blood 103:2942-2949

33. Hiasa $\mathrm{K}$, Ishibashi $\mathrm{M}$, Ohtani $\mathrm{K}$, Inoue $\mathrm{S}$, Zhao Q, Kitamoto $\mathrm{S}$, Sata M, Ichiki T, Takeshita A, Egashira K (2004) Gene transfer of stromal cell-derived factor-1alpha enhances ischemic vasculogenesis and angiogenesis via vascular endothelial growth factor/ endothelial nitric oxide synthase-related pathway: next-generation chemokine therapy for therapeutic neovascularization. Circulation 109:2454-2461

34. Abbott JD, Huang Y, Liu D, Hickey R, Krause DS, Giordano FJ (2004) Stromal cell-derived factor-1alpha plays a critical role in stem cell recruitment to the heart after myocardial infarction but is not sufficient to induce homing in the absence of injury. Circulation 110:3300-3305

35. Arras M, Ito WD, Scholz D, Winkler B, Schaper J, Schaper W (1998) Monocyte activation in angiogenesis and collateral growth in the rabbit hindlimb. J Clin Invest 101:40-50

36. De Palma M, Venneri MA, Galli R, Sergi Sergi L, Politi LS, Sampaolesi M, Naldini L (2005) Tie2 identifies a hematopoietic lineage of proangiogenic monocytes required for tumor vessel formation and a mesenchymal population of pericyte progenitors. Cancer Cell 8:211-226

37. van Weel V, Seghers L, de Vries MR, Kuiper EJ, Schlingemann RO, Bajema IM, Lindeman JH, Delis-van Diemen PM, van Hinsbergh VW, van Bockel JH, Quax PH (2007) Expression of vascular endothelial growth factor, stromal cell-derived factor-1, and CXCR4 in human limb muscle with acute and chronic ischemia. Arterioscler Thromb Vasc Biol 27:1426-1432 